\title{
Bio Encapsulation of Bio Control Agents for Effective Management of Collar Rot (Rhizoctonia solani) in Coffee (Coffea arabica)
}

\author{
S. Soundara Rajan*, S. Daivasikamani and A. Manoharan \\ Regional Coffee Research Station, Thandigudi, Dindigul District, Tamil Nadu, India \\ *Corresponding author
}

\section{A B S T R A C T}

Ke y w o r d s
Biocontrol,
Trichoderma
harzianum, Coffee
seed priming,
Rhizoctonia
solanai, and
bioencapsulation

Collar rot or damping off disease occurs on one to four month old tender coffee (Coffea Arabica) seedlings in the nursery. Sometimes, the collar rot pathogen infects coffee seeds sown on the seed beds and prevents the germination. However, the pathogen fails to establish in coffee seedlings when the stem at collar region turns brown in color and becomes harder. It is a soil inhibiting fungus with a wide host range including coffee. Collar rot disease is the most economical disease in coffee seedlings in India. The disease is caused by fungi Rhizoctonia solanai. The coffee growers apply chemical fungicides to control this pathogen. Hence development of alternatives to chemicals for the disease control is very much required. As an alternate strategy use of efficient strains of Trichoderma harzianum, Pseudomonas flurocense, Bacillus subtilis and Agrobacterium tumifaciense as bio control agents through effective formulations would be needed for proper control of collar rot in coffee. The strains were isolated and screened by antagonist activity test against $R$. solanai pathogen and encapsulated for field application. The efficient strains such as T. harzianum, P. flourocens, $B$. subtilis, and A. tumifaciense have been formulated in the form of solid, bioencapsulation for increasing the shelf life, facilitate easy application and effective control of collar rot disease. The formulated bio control agents were tested for their shelf life and field efficacy on the seedlings. The results of shelf life and disease incidence score revealed that the encapsulated formulations performed well in controlling the collar rot problem in coffee.

\section{Introduction}

The area of Coffee cultivation in Tamil Nadu is around 13436 ha with an average production of about 5654 metric tonnes and productivity 470 kilos per ha. However, pests and diseases are the major hurdles which considerably affect the production and productivity. Among the diseases Rhizoctonia solanai is the major one in coffee which causes collar rot. It is also widespread in traditional coffee growing areas and the disease severity is as high as $30-40$ per cent.
Collar rot or damping off disease occurs on 1 to 4 month old tender coffee seedlings in the coffee nursery. Sometimes, the collar rot pathogen attacks coffee seeds sown on the seed beds and prevent its germination.

However, the pathogen fails to establish on coffee seedlings when the stem at the collar region turn brown and become harder. It is a soil inhabiting fungus with a wide host range including coffee. The pathogen is capable of surviving in the soil for many months in the form of sclerotia under favorable conditions. 
Sclerotia germinate into mycelia and infect coffee seedlings. Two phases of this disease are described as under: 1) Pre - emergence stage: The pathogen invades embryo and endosperm of the nursery seed beds; consequently seeds start rotting, disintegrate and fail to germinate. 2) Post - emergence stage: Seedlings show brown to black discoloration at the collar region of the stem leading to rotting of the tissues. Growing tip of the seedlings wilts, Collapses and dies (Sudhakar and Bhat, 2016).

Control of plant diseases is considered as one of the viable alternative methods to manage plant diseases (Barakat and Al-Masri 2005, Pal and Gardener 2006). Application of fungicides is not economical in the long term because they pollute the environment; leave harmful residues and lead to development of resistant strains of the pathogen with repeated use (Vinale et al., 2008). However, biological control methods are safe, non-hazardous for human, farm animals and avoid environmental pollution. Application of biological controls using antagonistic microorganisms has proved to be successful for controlling various plant diseases in many countries (Janisiewicz 2000).

Among the several fungal bio control agents, Trichoderma harzianum, Bacillus subtilis, Pseudomonas flouroscens, Agrobacterium tumifaciense have been reported to control a wide range of plant pathogens for more than 70 years (Gary et al., 2008).

Studies indicated its wide range of biocontrol activity against pathogens such as Fusarium sp, Rhizoctonia, Pythium, Sclerotinia and Sclerotium (Veronica Azucena et al., 2010). Several species of T.harzianum, B.subtilis, P.flouroscens, A.tumifaciense are reported to suppress Rhizoctonia solanai pathogen by producing cell wall degrading enzymes like chitinases and $\beta$-1, 3-glucanase. Biocontrol agents have many advantageous characters when compared to the other control agents: fast growth, adaptation to a wide range of environmental conditions, propagation on a wide variety of carbon sources for mass production (Nakkeeran et al., 2005). For a successful bio-control strategy, a highly effective strain needs to be formulated in suitable form for its efficient action.

The types of formulation play a crucial role in deciding its effective action in the soil and plants when it is applied externally. It has been reported that the solid carrier based inoculants have many disadvantages like short shelf life, poor quality, high contamination, low and unpredictable field performances (Hedge, 2002).

On the other hand, encapsulated formulations have been reported to be more efficient due to high cell count, less contamination, longer shelf life and easy application. It has also shown greater protection against environmental stress and better field efficacy (Paula et al., 2011; Wang et al., 2002). Biopriming is a new technique of seed treatment that integrates biological (inoculation of seed with beneficial organism to protect seed) and physiological aspects (seed hydration) of disease control. It is an ecological approach using selected fungal antagonists against the soil- and seed-borne pathogens. Therefore, seed priming alone or in combination with low dosage of fungicides and/or biocontrol agents has been used to improve the rate and uniformity of emergence of seed and reduce damping-off disease (Parvatha Reddy 2012).

Encapsulation within a matrix protects the microbial biological control agent from biotic and abiotic stress factors such as contaminations, soil antagonists, temperature, dryness, UV light, mechanical stress and providing a beneficial microenvironment. 


\section{Coffee seed bio priming}

Coffee seed bio-priming is an advance technique of seed treatment that involves application of beneficial microorganisms on seed surface followed by low cost. Coffee seed bio priming is an ecological management of strategy to control seed and soil borne pathogens which will be an alternative to chemical treatment. Seed bio-priming enhance the initial step of growth by increased germination and protection of the pathogen by endophytic of bio control action before emergence of seedlings.

\section{Materials and Methods}

Several species of T.harzianum, B.subtilis, $P$. flouroscens, A. tumifaciense were isolated from rhizosphere of the plant from collar rot affected coffee fields. The strains were isolated in Trichoderma selective medium (TSM), Nutrient Agar, Kings B Agar and Sucrose sorbital Agar and identified the phenotypic characters such as colony morphology, growth rate, colony colour, colour change of media, the spore load and conidial structure and arrangements under microscope (Games and Meyer 1998).

Collar rot infected coffee seedlings were collected from coffee nursery at Thandikudi, Dindigul (Dt). Infected seedlings were washed under tap water for about 5 minutes to remove soil particles. Infected stem parts (1 to $2 \mathrm{~mm}$ ) were cut into small pieces by sterilized blade then surface sterilized with $70 \%$ alcohol for $1 \mathrm{~min}$. The pieces were then washed thrice with sterilized distilled water and dried by sterilized blotting paper. These pieces were placed in Petri dishes $(90-\mathrm{mm}$ diameter) containing $20 \mathrm{ml}$ Potato Dextrose Agar (Peeled potato $-200 \mathrm{~g}$, Dextrose $-20 \mathrm{~g}$, Agar- $15 \mathrm{~g}$ and distilled water $-1000 \mathrm{ml}, \mathrm{pH}$

- 5.6) medium amended with streptomycin $(250 \mathrm{mg} / \mathrm{L})$ and incubated at $28 \pm 2^{\circ} \mathrm{C}$ for 7 days. These isolated pathogen was purified separately by transferring the tip of the mycelia into PDA slants and Single spore culture of Rhizoctonia sp were maintained in PDA for long term use and pathogenicity was confirmed (Burgess et al., 1994).

\section{Laboratory screening of antagonists against the test pathogen}

Antagonistic ability of isolates against the test pathogen R.solani was estimated by using modified antagonistic index of Kasinathan (1998) who followed four criteria like Per cent Inhibition (PI) (Dennis and Webster, 1971), Selected four Trichoderma spp evaluated against $R$. solani by the dual culture technique (Morton and trouble 1955). Mycelial discs of $5 \mathrm{~mm}$ in diameter were excised from the edge of an actively growing antagonist and the pathogen was cultured on opposite ends of a petri dish equidistant from the periphery. A completely randomized experimental design was used with three replicates for each isolate. In control petridish, in place of antagonist, a sterile agar disc was inoculated on the side of opposite pathogen. Inoculated plates were incubated at $25 \pm 10 \mathrm{C}$ for $5-7$ days. After the incubation period, radial growth of pathogens was measured and the per cent inhibition of average radial growth was calculated relative to the controls as follows: $\mathrm{L}=[(\mathrm{C}-\mathrm{T}) / \mathrm{C}] \times$ 100.

The experiment revealed that $T_{1}$ resulted in higher inhibition of pathogen compared to control where $\mathrm{L}$ is the percentage inhibition of radial mycelial growth, $\mathrm{C}$ is radial growth of the pathogen in the control; $\mathrm{T}$ is radial growth of the pathogen in the presence of $T$. harzianum (Edington et al., 1971). The degree of antagonism between each of the Trichodema species and test pathogens in dual culture was scored on scale of R1 - R5 that is, $\mathrm{R} 1=$ Trichoderma completely overgrew 
pathogens (100\% over growth); R2 $=T$. harzianum overgrew at least two-third pathogens (75 \% over growth); R3 $=T$. harzianum colonizes on one half of the pathogens (50 \% over growth); $\mathrm{R} 4=T$. harzianum and the pathogens contact point after inoculation and R5 $=$ Pathogens overgrow bioagent - $T$. harzianum (Bell et al., 1982).

The efficient strains were developed as capsule formulations. The efficient strains were mass produced using low cost media, T.harzianum is multiplying in potato yeast broth medium and mixed with talc in the ratio of $1: 2.5$ and $0.5 \%$ carboxyl methyl cellulose (CFC) for solid based formulated products. For bio-encapsulation of T.harzianum, it was inoculated in modified Potato Dextrose Broth and the filtrate of 7 days grown culture was mixed with $50 \%$ sorghum flour, $50 \%$ Talcum powder, $0.5 \%$ CFC and $0.01 \%$ chitin. Then the formulated culture was filled in capsules for field application. Similar method was followed for encapsulated formulations of P.flourocens, B.subtilis, A. tumifaciense in the medium of Kings B, Nutrient broth, Sucrose sorbitol medium respectively.

The naked coffee seeds were sterilized by the technology of coating with beneficial microorganisms to remove soil borne pathogens and treated with microbial consortial bioagents for encapsulation and sown in the pots@ $@ 25$ seeds each. The samples were observed for percentage of germination and reduction in the infection rate of collar rot disease.

The formulated products were analysed for their shelf life from ' 0 ' day to 180 days and CFU was calculated at monthly interval. Population dynamics were analysed at different levels of soil moisture of 40, 60, 80 and $100 \%$ and $\mathrm{pH} 4.0$ (Kok et al., 1996).

\section{Nursery experiments}

The nursery experiment was conducted in coffee seedlings for determining the field efficacy of different formulations in one acre. Different methods of field application of virulent isolates, Carbandazim chemical fungicide were adopted along with control. Three treatments in three replicates for each:

\begin{tabular}{|l|l|l|}
\hline 1. & ST & Seedling Treatment \\
\hline 2. & $\begin{array}{l}\text { DR } \\
-\end{array}$ & Drenching $(0.5 \%)$ \\
\hline 3. & $\begin{array}{l}\text { Bio } \\
\text { priming - }\end{array}$ & $\begin{array}{l}\text { Sowing of bio prime } \\
\text { seeds }\end{array}$ \\
\hline
\end{tabular}

The observation on disease severity of collar rot in coffee was scored on a 1-5 scale (Ploetz and Bentley 2001) besides observation on the growth parameters.

\section{Statistical analysis}

Statistical analysis was done following a completely randomized design (CRD) with nine replicates in each treatment. The data was subjected to analysis of variance (ANOVA) using statistical software SPSS 10.0,1999 and significance of various treatments was evaluated by Duncan's multiple range tests (DMRT).

\section{Results and Discussion}

\section{Screening and selection of virulent strains}

Based on phenotypic observation the isolates were designated as Trichoderma. harzianum and Pseudomonas flouroscens, Bacillus subtilis, Agrobacterium sp. In T. harzianum, the hypha was septate, branched, smooth walled and colorless. The spore load was from $8 \times 10^{6 .} T$. harzianum was taken for sporulation from 3.0 to 6.0 days. $P$. flouroscens is rod shaped, the bacterial cell 
load was from $2 \times 10^{7}, B$. subtilis is a rodshaped bacterium that typically forms small clumps, short chains, or single cells and cell load in $1 \times 10^{7}$, A. tumifaciens Gram-negative, rod-shaped and cell load in $2 \times 10^{7}$. The pathogen profile in coffee plantation is more soil borne fungus so virulent strains effective of other than collar rot pathogen in coffee eco system.

\section{Antagonistic effect of biocontrol agents with rhizctonia}

Among the isolates $T$. harzianum and $P$. flouroscens, B. subtilis, A. tumifaciens. had 91.0 per cent of Inhibition. The colonization behavior of strains revealed that it completely overgrew on pathogen within $48 \mathrm{~h}$ to 72 hours of inoculation of both the antagonist and the pathogen. The highest per cent inhibition was observed with $T$. harzianum, P.fluorocens followed by B. subtilis (Fig.1)

\section{Effective formulations}

Based on the results, strains multiplied in $T$. harzianum and $P$. flouroscens, B. subtilis, A.tumifaciens are in 100 per cent colonization in the medium. The shelf life in talc formulation declined from $10^{8}$ to $10^{3} \mathrm{cfu} / \mathrm{g}$ from 0 to $180 \mathrm{DAS}$.

The shelf life of control was found to decline slowly from 0 days $\left(2.8 \times 10^{10} \mathrm{cfu} / \mathrm{g}\right)$ to 90 DAS $\left(18 \times 10^{7} \mathrm{cfu} / \mathrm{g}\right)$. There was a sharp decline from 30 days after storage and found below the load in 180 days from $2 \times 10^{10}$ to $19.3 \times 10^{7}$ of $T$. harzianum in capsule formulation.

Capsules formulated bioagents recorded higher level of spore survival throughout the period of observation followed by talc. Based on the results the shelf life was best in capsule amended formulations of all strains than talc formulation and control (Table:1, Plate 2).

\section{Population dynamics of biocontrol agents at different levels of soil moisture}

Comparison among different strains showed that the survival rate performed better at 40 to 60 per cent soil moisture. T.harzianum survival at $40 \%$ in cfu was 2.90 to $3.58,8.26$, Pseudomonas- 8.26 to 20.12, B.subtilis - 13.0 to 33.8. The results emphasized that P.flouroscens, B.subtilis and A. tumifaciense were superior in their performance and 100 per cent moisture was completely detrimental for the survival at field. Whereas, capsule formulation of T. harzianum and P. fluroscens was superior in its performance at 60 and 100 per cent moisture.

The experimental results (in-vitro) revealed that the bio agents of $P$. fluroscens and $T$. harzianum inhibited collar rot pathogen to the tune of $41 \%$ and $43 \%$ respectively compared to control. In nursery, it was observed that the use of P. flurocens resulted in the highest percentage of coffee seed germination (91\%) followed by A tumifaciens (89\%) compared to control (54\%). Hence, it may be concluded that the extent of inhibition of pathogen by $B$. subtilis and $T$. harzianum. The potential antagonistic controlling of $R$. solanai and germination on coffee seedlings by $P$. flurocens and A. tumifaciens performed well. Carbendazim significantly reduced the disease incidence compared to control. The maximum disease incidence was reduced in application of capsules + Drenching of $\mathrm{T}$. harzianum, P. fluorescens B. subtilis and A. tumifaciense and drastically controlled the rot disease in the coffee seedlings. The PGPR and B. subtilis strains controlled $50 \%$ of rot disease than control plants (Table:2, Plate 4).

Biopriming of coffee seeds resulted in germination upto $90 \%$ as compared to control and also disease incidence was reduced upto $95 \%$. So the requirement of coffee seeds can be reduced from 7500 nos to 
3000 per hectare( i.e $30 \%$ seeds are only required) and also the usage of chemical fungicide has drastically reduced (Plate 3 ) .

In the past, a number of Trichoderma formulations were evaluated against several fungal pathogens (Mathivanan et al., 2005), however, the carrier based bio-inoculants had short shelf life, high contamination and low field performance. In this context, the development of encapsulated biological inoculants assumes greater significance. But the overall analysis explained that, shelf life of bio control agent was accentuated from $10^{10}$ to $10^{7}$ with capsulated formulations followed by talc based upto 180 days after storage. Among the various cell protectants used, capsulation is a cheaper source, viable and also enhances the shelf life. While encapsulation science has moved to highly sophisticated capsule systems, the standard capsule in biological control remains the calcium alginate based. In the near future, formulations will aim to co-formulate longer persistence of capsules and therefore in longer persistence of the bio control agent (Marina Vemmer, Anant V. Patel 2013). In the present investigation while all the strains survived well at $40-80 \%$ soil moisture, 100 per cent moisture was completely detrimental. Similarly the bio control fungus was more effective in reducing the growth of the pathogen in moist than in wet soil (Haq et al., 2009).

Coffee seed biopriming technology shows that, it's an efficient technology for control of collar rot disease and increase the seed germination. Seeds are infected or contaminated with pathogens; fungal growth can be enhanced during priming, thus resulting in undesirable effects on plants. Parvatha Reddy (2012) reported that, seed priming alone or in combination with low dosage of fungicides and/or biocontrol agents has been used to improve the rate and uniformity emergence of seed and reduce damping-off disease. Begum et al., (2010), reported that Bio-priming with $P$. aeruginosa or $T$. harzianum offered an effective biological seed treatment system and an alternative to the fungicide Benlate for control of damping-off of soybean caused by $C$. truncatum of soybean.

Table.1 Effect of different cell protectants on the survival of T. harzianum with various formulations

\begin{tabular}{|c|c|c|c|}
\hline $\begin{array}{c}\text { Days After Sporulation } \\
\text { (DAS) }\end{array}$ & $\begin{array}{l}\text { Control - liquid } \\
\text { medium without } \\
\text { formulation }\end{array}$ & $\begin{array}{l}\text { Capsule } \\
\text { formulation }\end{array}$ & $\begin{array}{l}\text { Talc based } \\
\text { Formulation }\end{array}$ \\
\hline $\mathbf{0}$ & $16.4 \times 10^{10}$ & $18.2 \times 10^{12}$ & $\mathbf{4}^{12} \mathbf{1 0}^{8}$ \\
\hline $\mathbf{3 0}$ & $9.3 \times 10^{7}$ & $38.2 \times 10^{9}$ & $\mathbf{1 8 . 2 \times 1 0 ^ { 8 }}$ \\
\hline $\mathbf{6 0}$ & $27.5 \times 10^{4}$ & $17.1 \times 10^{8}$ & $\mathbf{7 . 1 \times 1 0 ^ { 7 }}$ \\
\hline $\mathbf{9 0}$ & $18.7 \times 10^{2}$ & $10.3 \times 10^{8}$ & $\mathbf{1 0 . 3}^{8} \mathbf{1 0}^{\mathbf{6}}$ \\
\hline $\mathbf{1 2 0}$ & - & $9.8 \times 10^{8}$ & $\mathbf{1 . 8}^{8} \mathbf{1 0}^{4}$ \\
\hline $\mathbf{1 5 0}$ & - & $1.5 \times 10^{8}$ & $\mathbf{1 9 . 5 \times 1 0 ^ { 3 }}$ \\
\hline $\mathbf{1 8 0}$ & - & $\mathbf{1 9 . 3 \times 1 0 ^ { 7 }}$ & $\mathbf{9 . 3} \times \mathbf{1 0}^{\mathbf{3}}$ \\
\hline
\end{tabular}


Table.2 Screening of bio-control (Antagonistic test) against Rhizoctonia solanai

\begin{tabular}{|l|c|c|}
\hline Treatments & Coffee seed germination (\%) & Collar rot incidence (\%) \\
\hline T1-Trichoderma harzianum & 82 & 18 \\
\hline T2- Epiphytic (PGPR) & 73 & 17 \\
\hline T3-Bacillus subtilis & 75 & 25 \\
\hline T4-Rhizoshere Bacteria & 86 & 14 \\
\hline T5-Agrobacterium tumifaciens & 89 & 11 \\
\hline T6-Psudomonas fluoresces & 91 & 9 \\
\hline T7-Carbendazim- 0.02\% & 74 & 26 \\
\hline T8-Control & 54 & 46 \\
\hline S.Em \pm & 1.033 & 1.027 \\
\hline CD $(\mathbf{P}=\mathbf{0 . 0 5 \% )}$ & 3.133 & 3.114 \\
\hline
\end{tabular}

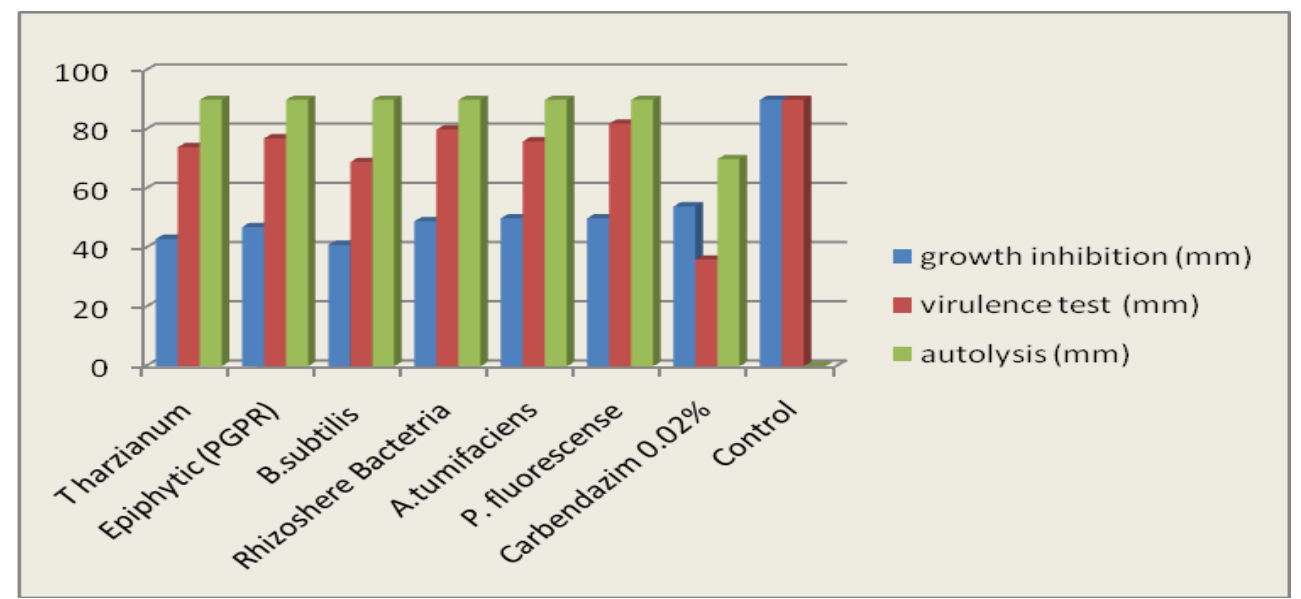

Fig.1 Antagonistic effects of Biocontrol agents against Rhizctonia sp

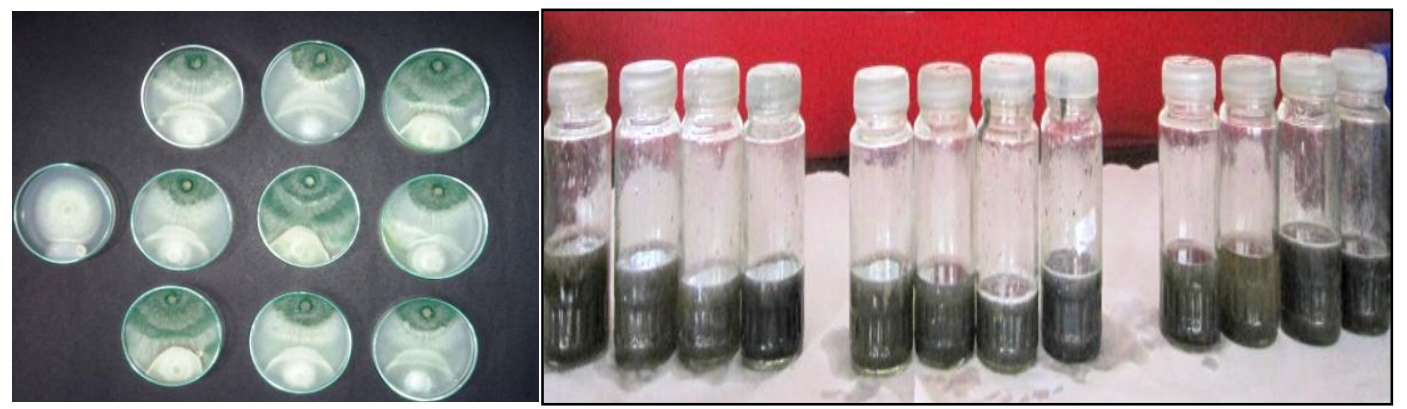

Plate.1 Antagonistic study against $R$. Solanai

Plate.2 shelf life study of $T$. harzianum
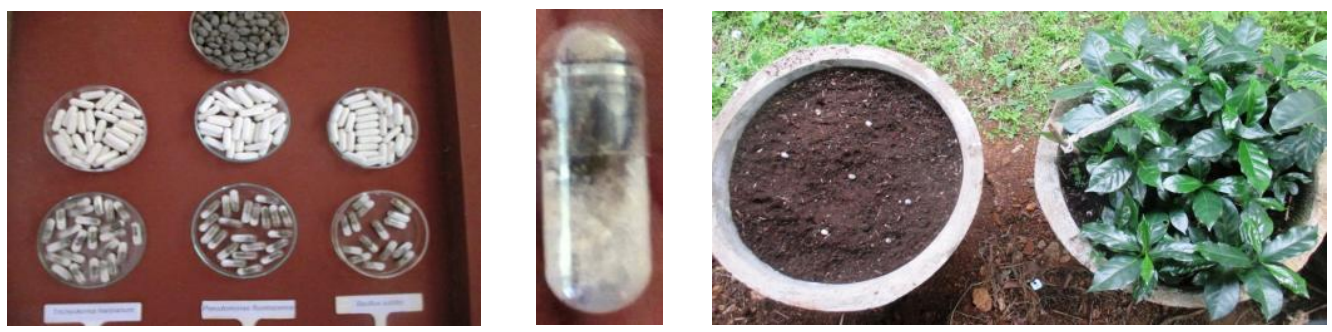

Plate.3 Biopriming of coffee seeds 

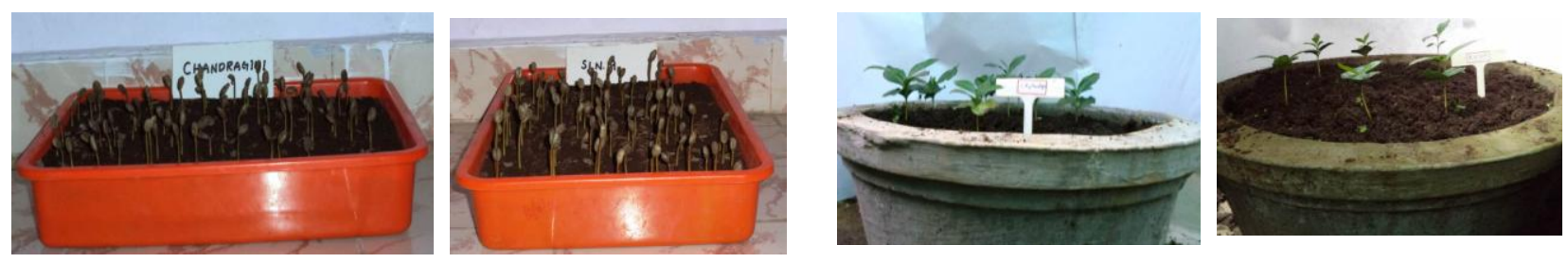

Plate.4 Field efficacy testing of Biocontrol agents

Different encapsulated formulations of biocontrol agents which were tested in the fields increased the plant growth and reduced the disease incidence in coffee significantly as compared to untreated control and also the chemical control. This was in accordance with the earlier findings of Wenhua et al., (1996) that feature that could make such agents more attractive is the possibility of enhancing plant growth in addition to disease control. From this study it is concluded that the T.viride and P.flourocens, B.subtilis, A.tumifaciense encapsulated formulations and seed biopriming technology proved as a better bio control agents for controlling rot diseases of Coffee besides promoting plant growth. Thus these effective formulations have the potential to be developed as good biocontrol agents in the near future for better crop yield.

\section{Acknowledgement}

The laboratory facilities provided by Regional Coffee Research Station to carry out this task is gratefully acknowledged

\section{References}

Barakat, R. and Al-Masri, M.I .2005. Biological control of gray mold disease (Botrytis cinerea) on tomato and bean plants by using local isolates of Trichoderma harzianum. Dirasat, Agricultural Sciences, 32: 145-156.

Begum, A., Sariah, M., Puteh, A.B., Zainal Abidin, M.A. , Rahman, M.A. and Siddiqui. Y. 2010. Field performance of bio-primed seeds to suppress
Colletotrichum truncatum causing damping-off and seedling stand of soybean Biological Control $53,18-23$.

Bell, D.K., Wells, H.D. and Markham, C.R. 1982. In vitro antagonism of Trichoderma spp. against six fungal plant pathogens. Phytopathology, 72: 379-382.

Burgess, L.W., Summerell, B.A., Bullock, S., Gott, K.P. and Backhouse, D. 1994. Laboratory Manual for Fusarium Research, 3rd Edition. Department of Crop Science, University of Sydney/Royal Botanic Gardens. 134

Dennis,C. and Webster, J. 1971. Antagonistic properties of species groups of Trichoderma. production of non-volatile antibiotics. Transactions of British Mycological Society. 57: 25-39.

Edington, L.V., Khew, K.L. and Barron, G.I. 1971. Fungitoxic spectrum of benzimidazole compounds. Phytopathology, 61, 42-44

Games, W. and Mayer, W. 1998. What exactly is Trichoderma harzianum. Mycologia. 5 : 901-915

Gary,E., Harman, Thomas Björkman, Kristen Ondik and Michal Shoresh. 2008. Changing paradigms on the mode of action and uses of Trichoderma sp. for biocontrol. Out looks on Pest Management.1- 6.

Hegde, S.V. 2002. Liquid Biofertilizers in Indian Agriculture. Biofertilizer Newsletter 21: 17-22.

Janisiewicz WJ, Tworkoski TJ, Sharer C 2000. Characterizing the mechanism of biological control of postharvest 
diseases on fruits with a simple method to study competition for nutrients. Phytopathology, 90: 1196-1200

Kasinathan, R. 1998. Studies on employing Trichoderma chitinases against certain plant pathogenic fungi. M.Sc.(Ag.). Thesis, Tamil Nadu Agricultural University, Coimbatore. 79

Kok, C.J., Hageman, P.E.J., Maas, P.W.T., Postma, J., Roozen, N.J.M. and Van Vuurde, J.W.L. 1996. Processed manure as carrier to introduce Trichoderma harzianum: Population dynamics and biocontrol effect on Rhizoctonia solani. Biocontrol Science and Technology. 6, 147-161.

Marina Vemmer, Anant V. Patel .2013. Review of encapsulation methods suitable for microbial biological control agents Biological Control 67(3):380 389.

Mathivanan, N., Prabhavathy, V.R., Vijayanandraj, V.R. 2005. Application of Talc Formulations of Pseudomonas fluorescens Migula and Trichoderma viride Pers. ex s.f. Gray Decrease the Sheath Blight Disease and Enhance the Plant Growth and Yield in Rice. Journal of Phytopathology. 153: 697-701

Nakkeeran, S., Renukadevi, P., Marimuthu, T. 2005. Antagonistic potentiality of Trichoderma viride and assessment of its efficacy for the management of cotton root rot. Archives of Phytopathology and Plant

Protection.38(3): 209 - 225.

Pal, K.K. and Gardener, B.M. 2006. Biological Control of Plant Pathogens.
The plant Health Instructor pp. 1-25.

Pavithra reddy, P. 2010 Bio-priming of Seeds Recent advances in crop protection $\mathrm{pp}$ 83-90

Ploetz, R.C. and Bentley, S. 2001. Pathogen Diversity in Coffee Fusarium wilt management towards sustainable cultivation. INIBAP, Los Baños (PHL. 293-294.

Srikant Kulkarni and Shalini D. Sagar. 2007. Tricoderma - a potential Biofungicide of the millennium - technical bulletin -5

Sudharkar, S.and Bhat. 2016. Coffee Guide, A Manual of Coffee Cultivation, Plant pathology, Chapter:19. integrated disease management Central Coffee Research Istitute, Karnataka, India. PP. 93- 115.

Veronica Azucena, Ibarra-Medina , Ronald Ferrera-Cerrato , Alejandro Alarcón , María Encarnación Lara-Hernández and Jorge Manuel Valdez-Carrasco. 2010. Isolation and screening of Trichoderma strains antagonistic to Sclerotinia sclerotiorum and Sclerotinia minor. Revista Mexicana De Micologia. 31: 53-63.

Vinale, F., Sivasithamparam, K., Ghisalberti, E.L., Marra, R. and Lorito, S.L. 2008. Trichoderma - plant pathogens interactions. Soil Biology \& Biochemistry, 40:1-10.

Wenhua, T., Gao Junming and Yang Hetong. 1996. Seed treatment by microorganisms for control of take-all and sharp eyespot of wheat. Advances in Biological Control of Plant Diseases. $1: 38-43$.

\section{How to cite this article:}

Soundara Rajan. S., S. Daivasikamani and Manoharan. A. 2020. Bio Encapsulation of Bio Control Agents for Effective Management of Collar Rot (Rhizoctonia solani) in Coffee (Coffea arabica). Int.J.Curr.Microbiol.App.Sci. 9(06): 1158-1166. doi: https://doi.org/10.20546/ijcmas.2020.906.144 